\title{
Ralstonia solanacearum Species Complex: A Quick Diagnostic Guide
}

\author{
Raymond O. García, Jim P. Kerns, and Lindsey Thiessen ${ }^{\dagger}$ \\ Department of Entomology and Plant Pathology, North Carolina State University, Raleigh, 27695
}

Accepted for publication 29 November 2018.

Hosts: The Ralstonia solanacearum species complex is composed of several $R$. solanacearum strains with low relatedness (Prior and Fegan 2005) and has a wide host range. The bacterium affects over 200 plant species within 50 different families, mainly dicotyledonous, herbaceous members of the Solanaceae family (Denny 2006). A few monocots, weeds, crops, shrubs, and trees are affected as well (Denny 2006; Genin and Denny 2012). Some of the primary high-value crops susceptible to $R$. solanacearum are summarized in Table 1.

Pathogen: $R$. solanacearum was first described by Erwin F. Smith in 1896 and was first named Bacillus solanacearum (Smith 1896). In 1914, Smith changed its name to Pseudomonas solanacearum (Smith 1896) Smith 1914. P. solanacearum was included in the Approved Lists of Bacterial Names (Skerman et al. 1980), and a substantial amount of literature was published under this name. Later, Yabuuchi et al. (1992) transferred P. solanacearum and related nonfluorescent pseudomonads to a novel genus called Burkholderia. Subsequently, Yabuuchi et al. (1995) concluded that Burkholderia solanacearum was distinct enough from other members within the genus to be assigned in the newly proposed genus Ralstonia. To date, the pathogen's preferred scientific name is Ralstonia solanacearum (Smith 1896) Yabuuchi et al. 1995 .

\section{Taxonomy}

$R$. solanacearum is a member of the nonfluorescent pseudomonads rRNA homology group II. The current $R$. solanacearum taxonomic state and infrasubspecific classification are shown in Tables 2 and 3, respectively, based on works by Prior et al. (2016), Remenant et al. (2011), and Safni et al. (2014) and the Taxonomy Browser tool on the National Center for Biotechnology Information website (https:// www.ncbi.nlm.nih.gov/Taxonomy/Browser/wwwtax.cgi).

\section{Symptoms and Signs}

Specific symptoms of $R$. solanacearum can vary among the wide range of susceptible hosts; however, general characteristics are shared among the host complex, including wilting and yellowing of younger leaves. The wilt is often unilateral (Fig. 1A), meaning that it is restricted to one side of the plant or one side of the leaf midvein (Denny 2006). Because R. solanacearum is found in high cell densities on infected tissues, a common sign of the pathogen is a milky white bacterial ooze that accumulates at the surface of freshly

${ }^{\dagger}$ Corresponding author: Lindsey Thiessen; E-mail: ldthiess@ncsu.edu

Funding: This work was funded by North Carolina State University.

(C) 2019 The American Phytopathological Society cut stems, rhizomes, or tubers (Denny 2006). In rare cases, when the cell density is low and the ooze does not form spontaneously, the "stem-streaming" test can be a useful diagnostic tool, especially in the field (Allen et al. 2001; Denny 2006; Momol and Champoiseau 2009). The stem-streaming test consists of placing a freshly cut stem segment in a clear vial containing water to induce the secretion of a viscous, white-creamy slime distinctive of $R$. solanacearum (Fig. 1B) (Momol and Champoiseau 2009). Additionally, symptom expression is directly affected by water availability and temperature. Generally, warmer temperatures above $28^{\circ} \mathrm{C}$ promote a faster symptom development than cooler temperatures (Denny 2006; Momol and Champoiseau 2009); however, symptoms may be slightly different across hosts and environmental conditions. A detailed description of the disease symptoms on representative hosts is provided below.

Tobacco. At the early stages of the disease cycle, the younger tobacco (Nicotiana tabacum) leaves are the first to wilt (Fig. 1C) (Denny 2006; Echandi 1991). As the disease progresses, the leaves turn yellow, and scorch-like symptoms may be expressed at the margins and between the veins, followed by a total collapse of the plant (Denny 2006). Stunting and leaf distortion may be observed in plants that do not die. Furthermore, primary and secondary roots may rot (Echandi 1991). When performing a cross section along the central axis, a reddish to brown discoloration of the vascular system, a hollow stem owing to the pith rotting, and lesions on the stem surface may be observed (Fig. 1D) (Denny 2006).

Tomato. Symptoms in tomato (Solanum lycopersicum) are similar to those observed on tobacco. These are first visible on the aboveground parts of the plant, specifically on the younger leaves (Fig. 1E) (Momol and Champoiseau 2009). However, the unilateral wilt may not be obvious, mainly owing to leaf size (Denny 2006). Under field conditions, wilt is often not observed until after flowering (McCarter 1991).

Potato. Wilting and chlorosis of the leaves located at the tip of the branches are the first visible symptoms of $R$. solanacearum infection on potato (Solanum tuberosum) (Denny 2006; Stevenson et al. 2001). Stunting and petiole epinasty may also occur (Denny 2006; Stevenson et al. 2001). Stem segments above the soil line may have dark brown streaks owing to necrosis and discoloration of the vascular system (Denny 2006; Stevenson et al. 2001). Secondary rotting, followed by death and desiccation, is common (Denny 2006). These symptoms may be observed at any phenological stage of the plant, and the rate at which they develop will be faster if the source of inoculum was an infected tuber used as vegetative material for propagation (Stevenson et al. 2001).

Belowground symptoms are important for identification of $R$. solanacearum on potatoes. Infected tubers can display a grayish brown discoloration of the vascular tissue and necrosis of the vascular ring and adjacent tissues (Denny 2006; Stevenson et al. 
2001). The periderm typically remains asymptomatic until the late stages of disease development (Denny 2006; Stevenson et al. 2001); however, in the case of infected young tubers, symptoms may be visible through the periderm if the bacterium is present at high cell

\section{TABLE 1}

Common and scientific names of some of the primary high-value crops affected by Ralstonia solanacearum

Host common

name

Tobacco

Tomato

Potato

Pepper

Eggplant

Bananas

Olive

Ginger

Geraniums

Mulberry

Groundnut

\section{Scientific name}

Disease common name ${ }^{a}$

${ }^{a}$ Disease common names as listed in the American Phytopathology Society (APS) Approved Revised Common Names of Plant Diseases website (https://www.apsnet.org/publications/commonnames/Pages/ default.aspx).

${ }^{\mathrm{b}}$ Disease common names are not listed in the APS Approved Revised Common Names of Plant Diseases website; therefore, we referred to them as "bacterial wilt."

\begin{tabular}{ll}
\multicolumn{2}{c}{ TABLE 2} \\
Ralstonia solanacearum current taxonomic state \\
Rank & \multicolumn{1}{c}{ Name } \\
Domain & Bacteria \\
Phylum & Proteobacteria \\
Class & $\beta$-Proteobacteria \\
Order & Burkholderiales \\
Family & Burkholderiaceae \\
Genus & Ralstonia \\
Species ${ }^{\text {a }}$ & R. detusculanense, $R$. insidiosa, $R$. mannitolilytica, $R$. \\
& pickettii, $R$. pseudosolanacearum, $R$. solanacearum, $R$. \\
& syzygii \\
\hline
\end{tabular}

${ }^{\text {a }}$ To date, the genus Ralstonia is composed of seven recognized species. densities (Stevenson et al. 2001). Bacterial ooze may emerge from the eyes of the tuber, and when it dries, soil can adhere to the tuber, providing a "smutty" appearance (Fig. 1F) (Stevenson et al. 2001). Brown rot is often confused with ring rot caused by Clavibacter michiganensis subsp. sepedonicus (Denny 2006; Stevenson et al. 2001); however, these can be distinguished based on signs and symptomatology because the bacterial streaming and vascular discoloration are not as evident in ring rot as they are in brown rot (Stevenson et al. 2001).

\section{Host Range}

Strains of $R$. solanacearum have different characteristics, including host range (Hong et al. 2012), which led researchers to classify bacterial strains to subspecies or intraspecies levels, such as races and biovars. To date, five races and six biovars of $R$. solanacearum have been identified based on host specificity (Buddenhagen et al. 1962) and on the bacterium's ability to acidify media containing different carbohydrate sources, reduce nitrate to nitrite, and denitrify from nitrate, respectively (Denny 2006; Hayward 1964). Despite being used for many years, race designation based on pathogenicity tests has proven to be unreliable (Genin and Denny 2012), because they are influenced by many factors such as host cultivar, growth conditions, inoculum concentration, and inoculation procedure (Denny 2006). Additionally, it does not correlate with phenotypic and ecological traits of the bacterium, allow accurate assessment of the genetic diversity at the infraspecific level, nor identify the evolutionary relationship between strains (Prior and Fegan 2005).

Owing to the inaccuracies of race and biovar classifications, current $R$. solanacearum infrasubspecific classification is based on phylotypes and sequevars (Hong et al. 2012). A phylotype is defined as a monophyletic cluster of strains revealed by phylogenetic analysis of sequence data, and phylotypes are equivalent to the subspecies level or even separate species (Fegan and Prior 2005). Four phylotypes have been identified based on sequence variation of the internal transcribed spacer region (Fegan and Prior 2005). A sequevar, also known as sequence variant, is defined as group of strains with a highly conserved sequence (Fegan and Prior 2005); currently, over 20 sequevars have been identified based on the partial endoglucanase gene (egl) sequence (Fegan and Prior 2005).

Race 1 is endemic in the Southeastern United States, has the broadest host range (Buddenhagen et al. 1962), and can be found across all the known phylotypes (Table 3 ). Phylotype II/sequevars 3, 4, and 6 (formerly race 2) affects triploid bananas (Musa spp.) and Heliconia spp., a tropical American relative of Musa spp. (Buddenhagen et al. 1962). Phylotype II/sequevars 1 and 2

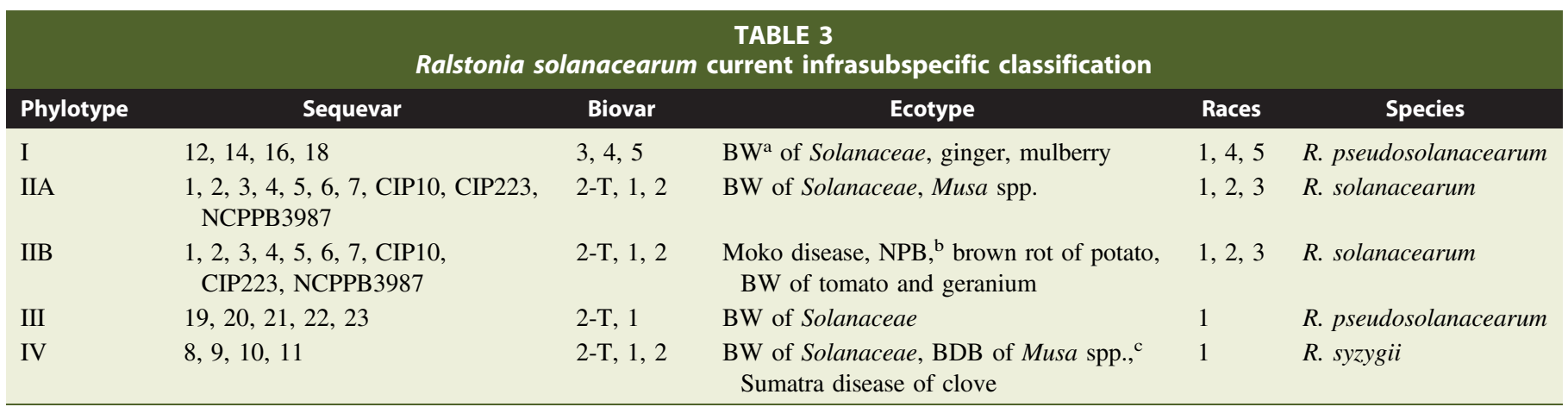

${ }^{\mathrm{a}} \mathrm{BW}=$ bacterial wilt.

b Nonpathogenic to banana (NPB) are new pathogenic variants highly virulent to Anthurium, Heliconia, and cucurbits but not to bananas.

${ }^{\mathrm{c}} \mathrm{BDB}=$ blood disease of banana 

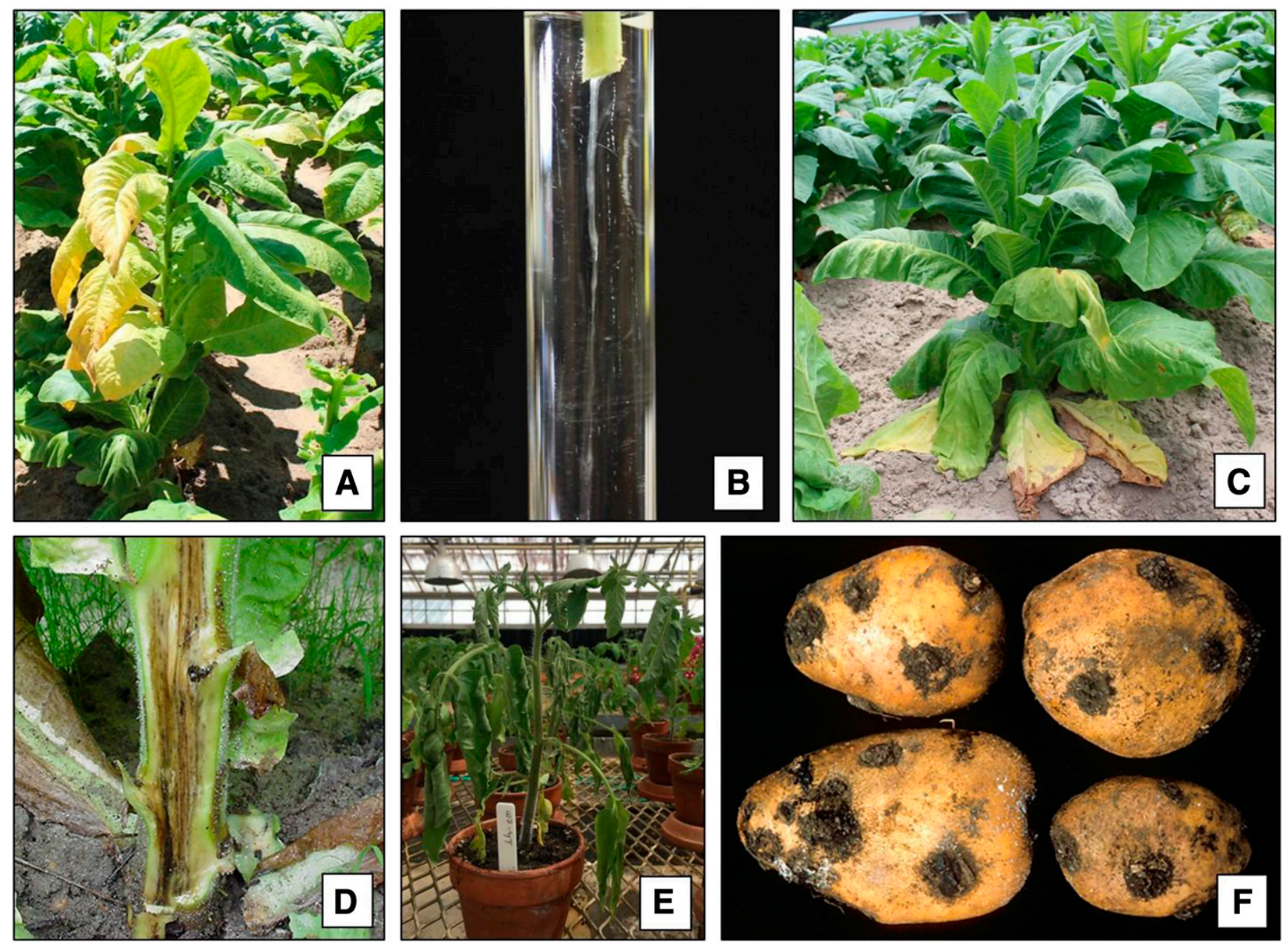

FIGURE 1

Ralstonia solanacearum distinctive symptoms and signs on representative hosts: A, unilateral yellowing and wilting of tobacco plant in the field; B, the stemstreaming test; $\mathbf{C}$, wilting of tobacco leaves in the field; $\mathbf{D}$, reddish to brown discoloration of the vascular tissue on tobacco stem; $\mathbf{E}$, wilting and yellowing of younger leaves of tomato in the greenhouse; and $\mathbf{F}$, periderm smutty appearance of potato tubers.

(formerly race 3 strains, including the former race 3/biovar 2A) cause bacterial wilt on potato and tomato (Buddenhagen et al. 1962) (Table 3). Lastly, races 4 and 5 (currently classified within phylotype I/sequevars 12, 14, 16, and 18) infect ginger and mulberry trees, respectively (Table 3) (He et al. 1983; Persley et al. 1986).

A table summarizing most, if not all, the hosts from which $R$. solanacearum has been reported can be found at the CABI website (https://www.cabi.org/isc/datasheet/45009).

\section{Geographic Distribution}

$R$. solanacearum has a worldwide distribution, owing in part to its wide host range. The bacterium is a ubiquitous soil inhabitant of all continents and many islands between the Tropics of Cancer and Capricorn. In this region, the average annual rainfall exceeds $100 \mathrm{~cm}$, the growing season is more than 6 months, the winter temperatures are higher than $10^{\circ} \mathrm{C}$, the average summer temperatures surpass $21^{\circ} \mathrm{C}$, and the average yearly temperature does not exceed $23^{\circ} \mathrm{C}$ (Denny 2006; Lucas 1975). Moraes (1947) first described the presence of strains capable of infecting potato even in temperate zones, where temperatures were $\leq 24^{\circ} \mathrm{C}$. These strains were later identified as race 3 biovar 2 (currently phylotype IIB/ sequevar 1), also known as the "potato race." Phylotype IIB/ sequevar 1 is listed as a select agent by the USDA Agricultural Bioterrorism Protection Act of 2002.

\section{Pathogen Isolation}

$R$. solanacearum can be isolated from water, soil, or symptomatic tissues. Regardless of the sample source, the sampled materials should ideally reach the laboratory facilities within $24 \mathrm{~h}$ from the time of collection (Kinyua et al. 2014). Isolating the bacterium from infected plant tissues can provide a pure culture, because the bacterial ooze produced by $R$. solanacearum is usually composed of pure bacterial cells (Denny 2006). Thus, small pieces of tissue excised from younger lesions can be surface sterilized, homogenized in sterile distilled water or $0.05 \mathrm{M}$ potassium phosphate buffer using a sterile mortar, streaked on standard low-ionic-strength bacteriological medium (e.g., modified Sequiera medium South Africa [SMSA] and triphenyl tetrazolium chloride [TZC]), and incubated for $48 \mathrm{~h}$ at 25 to $27^{\circ} \mathrm{C}$ (Table 4) (Denny 2006; Seleim et al. 2014). Some susceptible hosts will remain asymptomatic even when infected; SMSA should be used for these. 
Water and soil samples tend to have low populations of $R$. solanacearum, not all cells may grow in vitro, and higher levels of saprophytic bacteria and/or contaminants are present (Denny 2006). Therefore, these sample sources should be cultured on SMSA (Denny 2006). Lastly, pure cultures of $R$. solanacearum can be generated using the dilution streaking technique and selecting a single colony.

\section{Pathogen Identification}

$R$. solanacearum can be identified or detected using culturebased methods such as semiselective media, serological methods such as immune-strip tests and enzyme-linked immunosorbent assay, biochemical tests such as BIOLOG, fatty acids and protein analyses, and nucleic acid-based methods (Bekele et al. 2011; Denny 2006; Seal et al. 1993; Seal and Elphinstone 1994; Tran et al. 2016).

Traditional and rapid methods used for initial screening under field conditions include the stem-streaming test and commercially available $R$. solanacearum-specific immunoassay strips (Agdia,

\section{TABLE 4}

Recipes for the media commonly used for detection, isolation, and identification of Ralstonia solanacearum

Medium

Per liter

Casamino acid-peptone-glucose (CPG) $)^{\mathrm{a}, \mathrm{b}}$

(Kelman 1954)

Casamino acid (casein hydrolysate)

Peptone

Glucose

For solid media add

Agar

Triphenyl tetrazolium chloride

(TTC or TZC) $)^{\mathrm{a}, \mathrm{b}, \mathrm{c}}$ (Kelman 1954)

Casamino acid (casein hydrolysate)

Peptone

$1 \mathrm{~g}$

$10 \mathrm{~g}$

$5 \mathrm{~g}$

$17 \mathrm{~g}$

Glucose

For solid media add

Agar

Modified Sequiera medium South Africa

(SMSA) $^{\mathrm{a}, \mathrm{b}, \mathrm{c}}$ (Elphinstone et al. 1996)

Casamino acid (casein hydrolysate)

Peptone

Glycerol

For solid media add Agar

After autoclaving add ${ }^{\mathrm{d}}$

Crystal violet*

Polymyxin $\beta$ sulfate*

Bacitracin*

Chloromycetin*

Penicillin*

When inhibition of fungal

contaminants is desired, add

Cycloheximide*

\section{$1 \mathrm{~g}$}

$10 \mathrm{~g}$

$5 \mathrm{~g}$

$17 \mathrm{~g}$

$1 \mathrm{~g}$

$10 \mathrm{~g}$

$5 \mathrm{ml}$

$17 \mathrm{~g}$

$5 \mathrm{mg}$

$100 \mathrm{mg}$

$25 \mathrm{mg}$

$5 \mathrm{mg}$

$0.5 \mathrm{mg}$

$100 \mathrm{mg}$

${ }^{\mathrm{a}} \mathrm{pH}$ should be adjusted to 6.5 to 7.0.

${ }^{\mathrm{b}}$ Sterilize at $121^{\circ} \mathrm{C}$ and 15 psi for $20 \mathrm{~min}$.

${ }^{\mathrm{c}}$ Complement medium with $5 \mathrm{ml}$ of a $1 \%$ TZC solution. TZC has to be added after autoclaving and letting the medium cool down to approximately $55^{\circ} \mathrm{C}$. TZC stock solution can be filter sterilized or autoclaved for $5 \mathrm{~min}$ at $121^{\circ} \mathrm{C}$ and should be stored at $4^{\circ} \mathrm{C}$ or frozen.

${ }^{\mathrm{d}}$ Ingredients with an asterisk $\left(^{*}\right)$ next to them should be dissolved in $5 \mathrm{ml}$ of $70 \%$ ethanol 30 min prior to use and added after autoclaving.
Elkhart, IN) (Denny 2006; Kinyua et al. 2014). Streaking the bacterium on SMSA or TZC is another culture-based method commonly employed for initial screening (Denny 2006; Kinyua et al. 2014). Screening the bacterium on TZC allows differentiation between virulent and nonvirulent strains. Virulent strains generate white colonies with pink centers (Fig. 2A), whereas colonies of nonvirulent strains are dark red (Fig. 2B). On SMSA, colonies appear white with pink centers, fluidal, and irregularly shaped, just as they look on TZC. Lastly, when grown on casamino acid-peptone-glucose (CPG), virulent strains are white to cream colored, irregularly round, fluidal, and opaque (Fig. 2C). In contrast, nonvirulent colonies are uniformly round, smaller, and butyrous (Fig. 2D).

Although the techniques mentioned above are generally reliable and easy to perform, each has unique limitations. Serological tests have minimum cell thresholds for detection, do not differentiate between dead and live cells, and the rate of false positives increases proportionally with the number of contaminants in the sample (Denny 2006; Narayanasamy 2011). Furthermore, none of the assays allow identification of infrasubspecific levels, such as phylotype. To address these limitations and to provide high levels of confidence in identification, highly sensitive and specific nucleic acid-based methods such as conventional polymerase chain reaction (PCR), qPCR, microarray, and loop-mediated isothermal amplification have been developed (Cellier et al. 2017; Tran et al. 2016). $R$. solanacearum universal, phylotype, and sequevar- and strainspecific primers are available and widely used (Cellier et al. 2017; Fegan et al. 1998; Fegan and Prior 2005; Kubota et al. 2011; Opina et al. 1997; Stulberg et al. 2015; Weller et al. 2000; Yun et al. 2010). Some of the most commonly used nucleic acidbased methods are summarized in Table 5.

Recently, Tran et al. (2016) conducted a study in which they compared the sensitivity, cost-effectiveness, and technical complexity of multiple assays employed for the detection and identification of $R$. solanacearum. Although time consuming and laborious, culture enrichment combined with dilution plating was the most sensitive of the assays considered, capable of detecting up to $10^{1} \mathrm{CFU} / \mathrm{ml}$. Also, the sensitivity of PCR-based methods was enhanced by using a polymerase with enhanced performance in the presence of plant inhibitors. Additionally, bacterial cells were killed within 60 min of application to Whatman FTA nucleic acid-binding cards, suggesting that samples on FTA cards can be safely transported from the field to the labs for diagnosis without presenting a biosecurity threat (Tran et al. 2016). Lastly, they concluded that conducting PCR-based methods from FTA cards was faster, easier, and sensitive enough to detect cell densities as low as $10^{4} \mathrm{CFU} / \mathrm{ml}$.

In conclusion, the reliability and specificity of the methodology employed will depend on the purpose of the identification (Denny 2006). For example, if the identification is for quarantine purposes or to confirm the introduction of the pathogen to areas where it was not present, then reliable and unequivocal methods should be employed (Denny 2006).

\section{Pathogen Storage}

Pure cultures of $R$. solanacearum can be stored at room temperature $\left(20^{\circ} \mathrm{C}\right)$ in sterile tap, distilled, or deionized water (Champoiseau 2009). If stored in distilled or deionized water, cultures should be restreaked twice a year and repurified in the presence of nonmucoid colonies (Champoiseau 2009). Cryostorage in screw-capped vials containing CPG broth $(500 \mu \mathrm{l})$ amended with $20 \%$ glycerol $(600 \mu \mathrm{l})$ at $-70^{\circ} \mathrm{C}$ is most convenient for long-term storage (Champoiseau 2009; Kinyua et al. 2014). To stock a strain, transfer from a 2-day-old CPG or TZC plate grown at $30^{\circ} \mathrm{C}$ (Champoiseau 2009). R. solanacearum can lose viability, or 

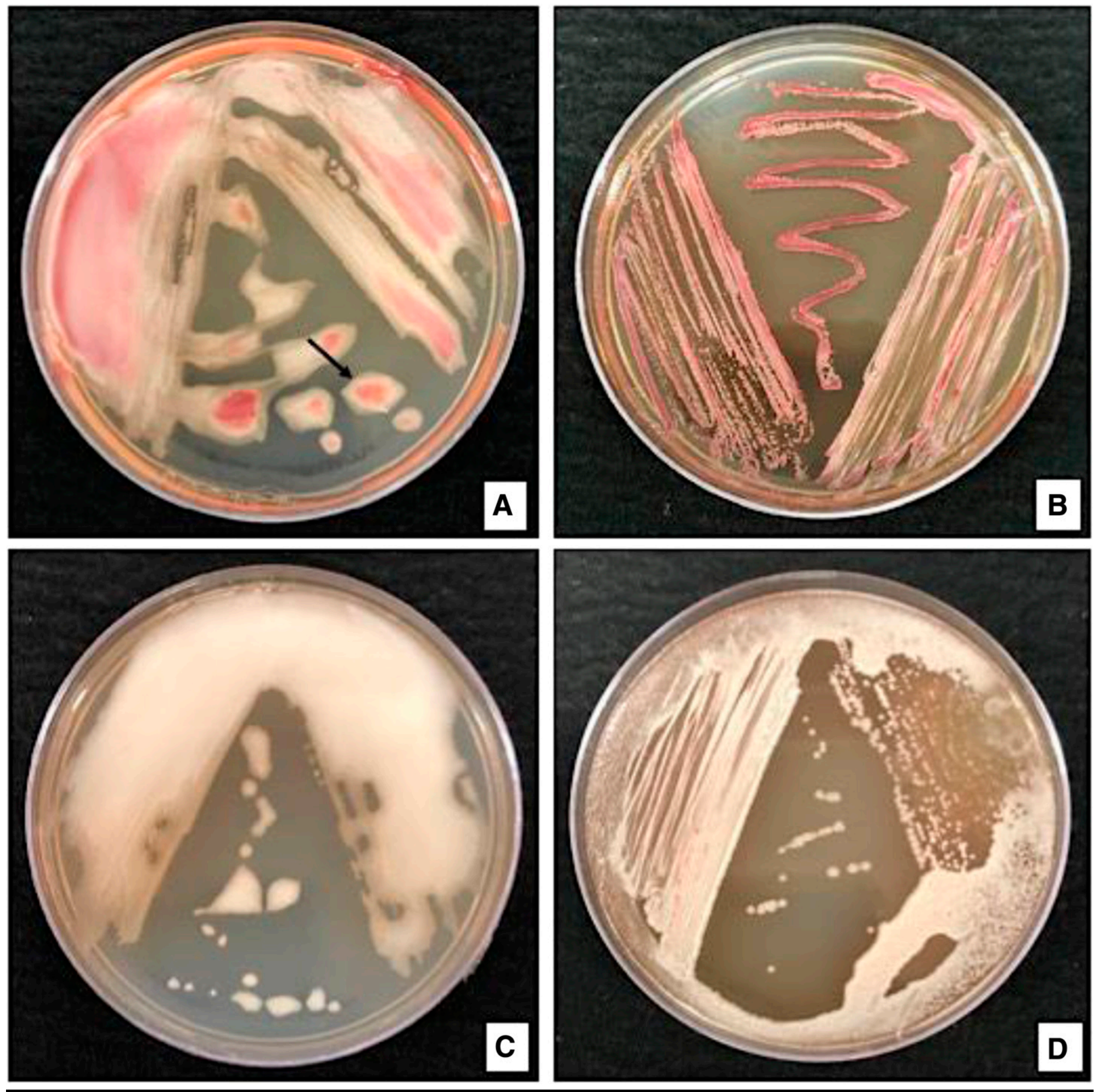

FIGURE 2

A, On triphenyl tetrazolium chloride (TZC), virulent strains produce a white with pink center, irregularly round, and fluidal colony (black arrow); B, avirulent strains produce a smaller, dark-red and regularly round colony on TZC; $\mathbf{C}$, virulent strains are white or cream-colored, irregularly round, fluidal, and opaque colony on casamino acid-peptone-glucose (CPG); and D, avirulent strains are white or cream-colored, smaller, regularly round, and opaque colony on CPG.

cultures may become viable but nonculturable, if they are exposed to low temperatures $\left(4^{\circ} \mathrm{C}\right)$ (van Elsas et al. 2001).

\section{Pathogenicity Tests}

For pathogenicity tests, soil drenching is one of the most common methods used for inoculation. Soil drenching or root inoculation often consists of wounding the roots and pouring 30 to $50 \mathrm{ml}$ of a $10^{8} \mathrm{CFU} / \mathrm{ml}$ (optical density [OD] at $600 \mathrm{~nm}$ wavelength $=0.1$ ) bacterial suspension close to the crown of the plant (Hong et al.
2012). Strains are generally inoculated on 3- to 4-week old plants (four to five true leaves) (Hong et al. 2012). The inoculated plants are typically transferred to either a growth room with a 12-h light/dark cycle with an approximate temperature of $30^{\circ} \mathrm{C}$ (Hong et al. 2012) or a greenhouse. Stem injection is another common method used for inoculation during pathogenicity tests and is typically carried out by puncturing the stem with a needle and injecting $100 \mu \mathrm{l}$ of bacterial suspension $(\mathrm{OD}=0.1$ ) (Winstead and Kelman 1952). For disease severity assessment, disease incidence is 
TABLE 5

Available nucleic acid-based tools for the detection and identification of the Ralstonia solanacearum species complex

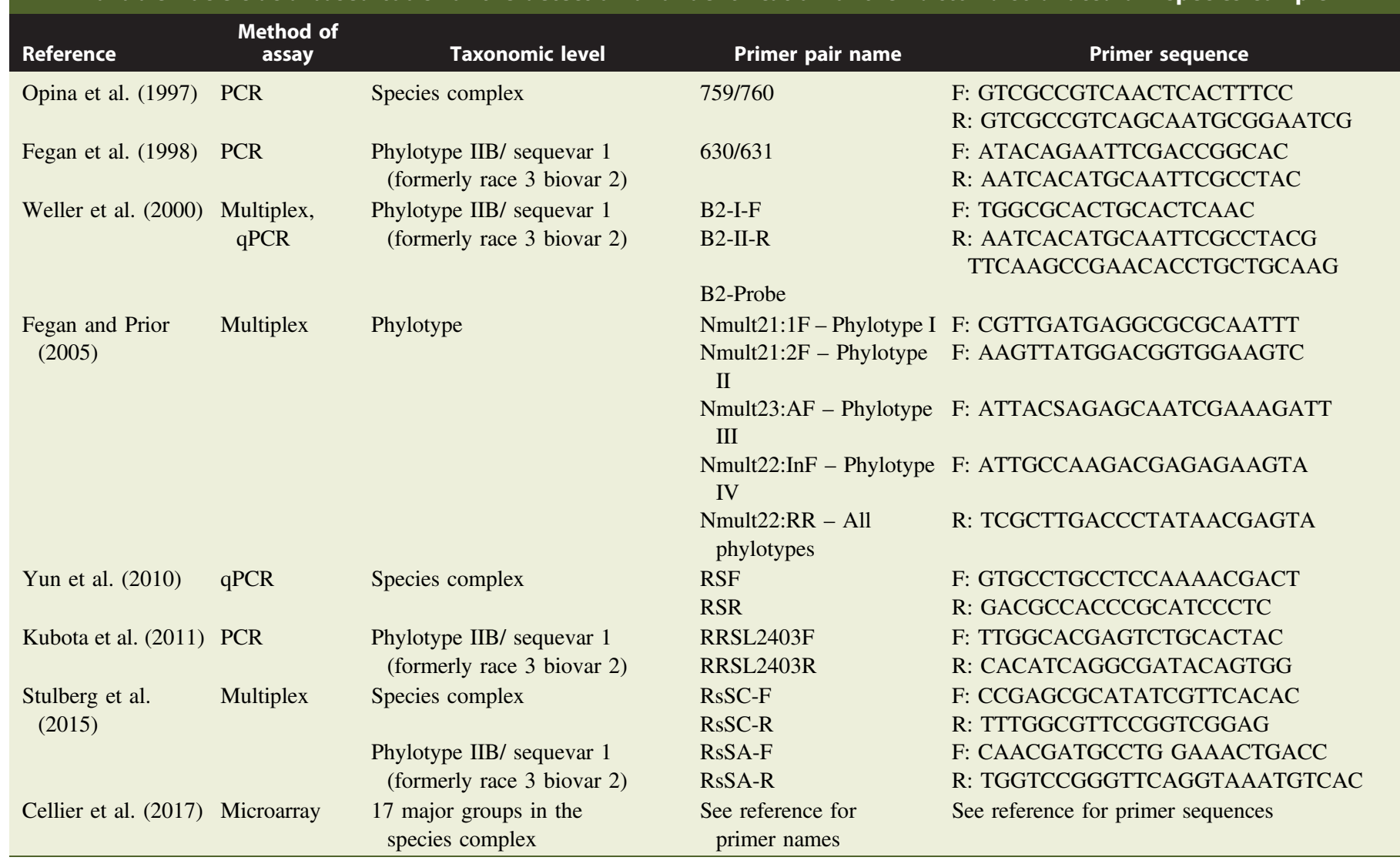

commonly used, but other methods such as wilt index are used as well (Winstead and Kelman 1952).

Recently, Singh et al. (2018) developed a pathogenicity assay performed under gnotobiotic conditions. Using the method developed, tomato seedlings showed wilting symptoms approximately $48 \mathrm{~h}$ postinoculation, and the pathogenicity assay could be completed within 2 weeks (Singh et al. 2018). Six- to 7-day-old tomato seedlings were root-dip inoculated in a bacterial suspension with an adjusted concentration of $10^{9} \mathrm{CFU} / \mathrm{ml}$ and transferred to $2.0-\mathrm{ml}$ sterile microcentrifuge tubes. Prior to the addition of 1 to $1.5 \mathrm{ml}$ of sterile water, the root-dip-inoculated tomato seedlings were subjected to air exposure for approximately $5 \mathrm{~min}$. All the inoculated seedlings along with controls were transferred to a growth chamber maintained at $28^{\circ} \mathrm{C}, 75 \%$ relative humidity, and a 12-h photoperiod (Singh et al. 2018). Lastly, seedlings were analyzed for disease progression from the next day onward until the seventh day postinoculation (Singh et al. 2018). The innovative pathogenicity assay is economic in terms of space, labor, and cost, as well as the required quantity of bacterial inoculum, and also useful for studying known virulence genes of $R$. solanacearum such as $h r p B$, phcA, and pilT (Singh et al. 2018).

\section{Literature Cited}

Allen, C., Kelman, A., and French, E. R. 2001. Brown rot. Pages 11-13 in: Compendium of Potato Diseases. W. R. Stevenson, R. Loria, G. D. Franc, and D. P. Weingartner, eds. American Phytopathological Society, St. Paul, MN.

Bekele, B., Abate, E., Asefa, A., and Dickinson, M. 2011. Incidence of potato viruses and bacterial wilt disease in the west Amhara sub-region of Ethiopia. J. Plant Pathol. 93:149-157.
Buddenhagen, I., Sequeira, L., and Kelman, A. 1962. Designation of races in Pseudomonas solanacearum. (Abstr.) Phytopathology 52:726.

Cellier, G., Arribat, S., Chiroleu, F., Prior, P., and Robène, I. 2017. Tube-wise diagnostic microarray for the multiplex characterization of the complex plant pathogen Ralstonia solanacearum. Front. Plant Sci. 8:821.

Champoiseau, P. G. 2009. Protocols for Ralstonia solanacearum culture preservation. https://plantpath.ifas.ufl.edu/rsol/CulturePreservation.html

Denny, T. P. 2006. Plant pathogenic Ralstonia species. Pages 573-644 in: PlantAssociated Bacteria. S. S. Gnanamanickam, ed. Springer, Dordrecht, the Netherlands.

Echandi, E. 1991. Bacterial wilt. Pages 33-35 in: Compendium of Tobacco Diseases. H. D. Shew and G. B. Lucas, eds. American Phytopathological Society, St. Paul, MN.

Elphinstone, J. G., Hennessy, J., Wilson, J. K., and Stead, D. E. 1996. Sensitivity of different methods for the detection of Pseudomonas solanacearum in potato tuber extracts. EPPO/OEPP Bull. 26:663-678.

Fegan, M., Holoway, G., Hayward, A. C., and Timmis, J. 1998. Development of a diagnostic test based on the polymerase chain reaction to identify strains of $R$. solanacearum exhibiting the biovar 2 genotype. Pages 34-43 in: Bacterial Wilt Disease: Molecular and Ecological Aspects. P. Prior, C. Allen, and J. Elphinstone, eds. Springer Verlag, Berlin, Germany.

Fegan, M., and Prior, P. 2005. How complex is the Ralstonia solanacearum species complex? Pages 449-461 in: Bacterial Wilt: The Disease and the Ralstonia solanacearum Species Complex. C. Allen, P. Prior, and A. C. Hayward, eds. American Phytopathological Society, St. Paul, MN.

Genin, S., and Denny, T. P. 2012. Pathogenomics of the Ralstonia solanacearum species complex. Annu. Rev. Phytopathol. 50:67-89.

Hayward, A. C. 1964. Characteristics of Pseudomonas solanacearum. J. Appl. Bacteriol. 27:265-277.

He, L. Y., Sequeira, L., and Kelman, A. 1983. Characteristics of strains of Pseudomonas solanacearum from China. Plant Dis. 67:1357-1361.

Hong, J. C., Norman, D. J., Reed, D. L., Momol, M. T., and Jones, J. B. 2012. Diversity among Ralstonia solanacearum strains isolated from the southeastern United States. Phytopathology 102:924-936.

Kelman, A. 1954. The relationship of pathogenicity in Pseudomonas solanacearum to colony appearance on a tetrazolium medium. Phytopathology 44:693-695. 
Kinyua, Z. M., Miller, S. A., Ashlina, C., and Subedi, N. 2014. Bacterial wilt disease Ralstonia solanacearum: Standard operating procedure for use in diagnostic laboratories. https://ipmil.cired.vt.edu/wp-content/uploads/2014/ 06/SOP-Ralstonia-solanacerum-EastAfricaFinal-Apr2014-2.pdf

Kubota, R., Schell, M. A., Peckham, G. D., Rue, J., Alvarez, A. M., Allen, C., and Jenkins, D. 2011. In silico genomic subtraction guides development of highly accurate, DNA-based diagnostics for Ralstonia solanacearum race 3 biovar 2 and blood disease bacterium. J. Gen. Plant Pathol. 77:182-193.

Lucas, G. B. 1975. Diseases of Tobacco, 3rd Ed. Biological Consulting Associates, Raleigh, NC.

McCarter, S. M. 1991. Bacterial wilt. Pages 28-29 in: Compendium of Tomato Diseases. J. B. Jones, J. P. Jones, R. E. Stall, and T. A. Zitter, eds. American Phytopathological Society, St. Paul, MN.

Momol, P. G. C., and Champoiseau, T. M. 2009. Bacterial wilt of tomato. https:// plantpath.ifas.ufl.edu/rsol/RalstoniaPublications_PDF/BacterialWiltTomato_ Revised_PDF.pdf.

Moraes, M. A. 1947. A vascular disease of potato (Bacterium solanacearum) E. F. Smith. (Uma bacteriose vascular da batateira (Bacterium solanacearum) E.F. Smith.). Agron. Lusit. 9:277-328.

Narayanasamy, P. 2011. Diagnosis of bacterial diseases of plants. Pages 233-246 in: Microbial Plant Pathogens-Detection and Disease Diagnosis, Vol.2: Bacterial and Phytoplasmal Pathogens. Springer, Dordrecht, the Netherlands.

Opina, N., Tavner, F., Hollway, G., Wang, J. F., Li, T. H., Maghirang, R., Fegan, M., Hayward, A. C., Krishnapillai, V., and Hong, W. F. 1997. A novel method for development of species and strain-specific DNA probes and PCR primers for identifying Burkholderia solanacearum (formerly Pseudomonas solanacearum). Asia Pac. J. Mol. Biol. Biotechnol. 5:19-30.

Persley, G. J., Batugal, P., Gapasin, D., and Vander Zaag, P. 1986. Summary of discussion and recommendations. Pages 7-13 in: Bacterial Wilt Disease in Asia and the South Pacific. G. J. Persley, ed. Australian Centre for International Agricultural Research, Canberra.

Prior, P., Ailloud, F., Dalsing, B. L., Remenant, B., Sanchez, B., and Allen, C. 2016. Genomic and proteomic evidence supporting the division of the plant pathogen Ralstonia solanacearum into three species. BMC Genomics 17:90.

Prior, P., and Fegan, M. 2005. Diversity and molecular detection of Ralstonia solanacearum race 2 strains by multiplex PCR. Pages 405-414 in: Bacterial Wilt Disease and the Ralstonia solanacearum Species Complex. C. Allen, P. Prior, and A. C. Hayward, eds. American Phytopathological Society, St. Paul, MN.

Remenant, B., Cambiaire, J. C., Cellier, G., Jacobs, J. M., Mangenot, S., Barbe, V., Lajus, A., Vallenet, D., Medigue, C., Fegan, M., Allen, C., and Prior, P. 2011. Ralstonia syzygii, the blood disease bacterium and some Asian $R$. solanacearum strains form a single genomic species despite divergent lifestyles. PLoS ONE 6:e24356.

Safni, I., Cleenwerck, I., De Vos, P., Fegan, M., Sly, L., and Kappler, U. 2014. Polyphasic taxonomic revision of the Ralstonia solanacearum species complex: Proposal to emend the descriptions of Ralstonia solanacearum and Ralstonia syzygii and reclassify current $R$. syzygii strains as Ralstonia syzygii subsp. syzygii subsp. nov., $R$. solanacearum phylotype IV strains as Ralstonia syzygii subsp. indonesiensis subsp. nov., banana blood disease bacterium strains as Ralstonia syzygii subsp. celebesensis subsp. nov. and $R$. solanacearum phylotype I and III strains as Ralstonia pseudosolanacearum $\mathrm{sp}$. nov. Int. J. Syst. Evol. Microbiol. 64:3087-3103.
Seal, S. E., and Elphinstone, J. G. 1994. Advances in identification and detection of Pseudomonas solanacearum. Pages 35-57 in: Bacterial Wilt: The Disease and Its Causative Agent, Pseudomonas solanacearum. A. C. Hayward and G. L. Hartman, eds. CAB International, Wallingford, U.K.

Seal, S. E., Jackson, L. A., Young, J. P. W., and Daniels, M. J. 1993. Differentiation of Pseudomonas solanacearum, Pseudomonas syzygii, Pseudomonas pickettii and blood disease bacterium by partial 16S rRNA sequencing: Construction of oligonucleotide primers for sensitive detection by polymerase chain reaction. J. Gen. Microbiol. 139:1587-1594.

Seleim, M. A. A., Abo-Elyousr, K. A. M., Abd-El-Moneem, K. M., and Saead, F. A. 2014. First report of bacterial wilt caused by Ralstonia solanacearum biovar 2 race 1 on tomato in Egypt. Plant Pathol. J. 30:299-303.

Singh, N., Phukan, T., Sharma, P. L., Kabyashree, K., Barman, A., Kumar, R., Sonti, R. V., Genin, S., and Ray, S. K. 2018. An innovative root inoculation method to study Ralstonia solanacearum pathogenicity in tomato seedlings. Phytopathology 108:436-442.

Skerman, V. B. D., McGowan, V., and Sneath, P. H. A. 1980. Approved lists of bacterial names. Int. J. Syst. Bacteriol. 30:255-420.

Smith, E. F. 1896. A Bacterial Disease of the Tomato, Eggplant, and Irish potato (Bacillus solanacearum nov. sp.). U.S. Department of Agriculture, Washington, DC.

Smith, E. F. 1914. Bacteria in Relation to Plant Diseases. Carnegie Institute, Washington, DC.

Stevenson, W. R., Loria, R., Franc, G. D., and Weingartner, D. P. 2001. Compendium of Potato Diseases. American Phytopathological Society, St. Paul, MN.

Stulberg, M. J., Shao, J., and Huang, Q. 2015. A multiplex PCR assay to detect and differentiate select agent strains of Ralstonia solanacearum. Plant Dis. 99:333-341.

Tran, T. M., Jacobs, J., Huerta, A., Milling, A., Weibel, J., and Allen, C. 2016. Sensitive, secure detection of race 3 biovar 2 and native U.S. strains of Ralstonia solanacearum. Plant Dis. 100:630-639.

van Elsas, J. D., Kastelein, P., de Vries, P. M., and van Overbeek, L. S. 2001. Effects of ecological factors on the survival and physiology of Ralstonia solanacearum bv. 2 in irrigation water. Can. J. Microbiol. 47:842-854.

Weller, S. A., Elphinstone, J. G., Smith, N. C., Boonham, N. and Stead, D. E. 2000. Detection of Ralstonia solanacearum strains with a quantitative, multiplex, real-time, fluorogenic PCR (TaqMan) assay. Appl. Environ. Microbiol. 66:2853-2858.

Winstead, N. N., and Kelman, A. 1952. Inoculation techniques for evaluating resistance to Pseudomonas solanacearum. Phytopathology 42:628-634.

Yabuuchi, E., Kosako, Y., Oyaizu, H., Yano, I., Hotta, H., Hashimoto, Y., Ezaki, T., and Arakawa, M. 1992. Proposal of Burkholderia gen. nov. and transfer of seven species of the genus Pseudomonas homology group II to the new genus, with the type species Burkholderia cepacia (Palleroni and Holmes 1981) comb. nov. Microbiol. Immunol. 36:1251-1275.

Yabuuchi, E., Yano, I., Hotta, H., Nishiuchi, Y., and Kosako, Y. 1995. Transfer of two Burkholderia and an Alcaligenes species to Ralstonia gen. nov.: Proposal of Ralstonia pickettii (Ralston, Palleroni and Doudoroff 1973) comb. nov., Ralstonia solanacearum (Smith 1896) comb. nov. and Ralstonia eutropha (Davis 1969) comb. no. Microbiol. Immunol. 39:897-904.

Yun, C., Zhang, W. Z., Liu, X., Ma, Z. H., Li, B., Allen, C., and Guo, J. H. 2010. A real-time PCR assay for the quantitative detection of Ralstonia solanacearum in the horticultural soil and plant tissues. J. Microbiol. Biotechnol. 20:193-201. 